ISSN 0258-7122 (Print), 2408-8293 (Online)

Bangladesh J. Agril. Res. 41(2): 207-219, June 2016

\title{
EFFECT OF DROUGHT STRESS ON AGRO-MORPHOLOGICAL TRAITS OF LENTIL (Lens culinaris Medik.) RECOMBINANT INBRED LINES
}

\author{
M. H. RAHIMI ${ }^{1}$, S. HOUSHMAND ${ }^{2}$, M. KHODAMBASHI ${ }^{2}$ \\ B. SHIRAN ${ }^{2}$ AND S. MOHAMMADY ${ }^{2}$
}

\begin{abstract}
To evaluate the effect of drought stress on agro-morphological traits of lentil, an experiment was conducted using 168 F6:7 inbred lines along with their parents in RCB design with three replications. Analysis of variance revealed significant differences among lines in terms of all studied characters in both normal and stress conditions. Comparing with non-stress condition, drought stress reduced pod weight per plant, seed yield and pod number per plant to $54 \%, 45.3 \%$ and $42.2 \%$, respectively. Correlation coefficient of biological yield, pod number per plant, pod weight per plant and harvest index (HI) with seed yield was positive and significant. Stepwise regression analysis showed that biological yield, HI, pod weights per plant and leaf length determined $87.6 \%$ of seed yield variations and biological yield had the most function. Maximum values of genotypic and phenotypic coefficient of variations were observed for seed yield, pod weight per plant and pod number per plant. The highest values of heritability found in leaf width $\left(h^{2}=0.77\right)$, seed diameter $\left(h^{2}=0.69\right)$ and plant height $\left(h^{2}=0.66\right)$. Evaluation of stress tolerance index (STI) showed that lines 125 and 160 were the most tolerant lines, which could be recommended for cultivation in areas that subject to terminal drought stress.
\end{abstract}

Keywords: lentil, drought stress, recombinant lines, genotypic parameters, yield components.

\section{Introduction}

Legumes are being commonly cultivated in the arid and semi-arid regions in the world. The crops have been considered as a part of important human diet especially in the developing countries (Wang et al., 2003). Lentil (Lens culinaris Medik.) is an annual diploid self-pollinated legume species that is used in human diet and animal feed as well owing to high protein (up to 28\%), micro-nutrient of iron, zinc and beta-carotene (Sarker et al., 2003; Erskine and Sarker, 2004). FAO (2013) reported that world production of lentil was 4.9 million tons with an average yield of $970 \mathrm{~kg} / \mathrm{ha}$. The area harvested of lentil in Iran was about 120000 ha with a yield average of $608.33 \mathrm{~kg} / \mathrm{ha}(\mathrm{FAO}, 2013)$. Although lentil originated from Mediterranean areas, it is adapted to hot and semi-arid areas and is

${ }^{1} \mathrm{PhD}$ Student, ${ }^{2}$ Professor, Department of Plant breeding and Biotechnology, Shahrekord university, Shahrekord, Iran. 
cultivated in Eastern Asia, North Africa, Indian subcontinent, North America, South America and Australia (Muehlbauer, 2009).

Agro-morphological traits are very important in crop improvement programs. Breeding for these characters along with the crop adaptation, agronomic performance, market value and demands for special uses are the major factors that improve the breeding goals of a crop (Saha et al., 2013). Plant breeders use morphological characters such as plant height, pod number, length and width of leaf, days to flowering, days to maturity, etc. and seed yield as selection criteria (Bayoumi, 2008).

Drought stress is a common concern for successful crops production in many areas of the world. This abiotic stress accrues when the combination of physical and environmental factors cause the inner tension in plant and reduce the yield (Blum, 2002). Water deficit affects almost all morphological and physiological traits that related to growth and decreased even 50\% crop yield (Wang et al., 2003). Lentil which is mostly grown as a rainfed crop often faces terminal moisture stress in arid regions that led to early maturity and low yield. Yield of lentil in Iran is less than average of the world because it is cultivated after downfall season with low humidity. In Mediterranean environments, lentil is subjected to periodic drought stress during the growth season, too (Silim et al., 1993). According to Oweis et al. (2004) drought stress reduced 6 to 54 percentage of lentil yield and production functions relating lentil yield with field water supply under supplemental and rainfed conditions. As a result, drought is considered as the main barrier of lentil yield (Fouad et al., 2011).

In order to develop genotypes resistant to drought, it is necessary for breeder to identify the lentil genotypes with high yield and resistant in confrontation to drought stress. Knowledge of genetic diversity, which exists among different lines of lentil for yield and its components, promotes the program of plant breeding. So far, genetic diversity among lentil genotypes in drought prone-areas has not been studied enough (Kumar et al., 2012). Therefore, special attention was paid on genetic diversity of cultivated genotypes of lentil in drought prone area for attempting a programmatic breeding program. The objectives of present study were to investigate the genetic diversity related to biological yield, pod number per plant, pod weight per plant, 100 grain weight, plant height, leaf length, leaf width, seed diameter and harvest index (HI) of lentil genotypes under normal and drought stress conditions.

\section{Materials and Method}

\section{Plant material}

In this study, agro-morphological traits were evaluated in 168 lines of a F6:7 population with their parents. This population was generated from cross between 
L3685 (a small seeded line as female parent) and Ghazvin (a large seeded line as male parent).

\section{Field experiment}

The experiment was conducted in the research field of Shahrekord University, Shahrekord, Iran during the period from March to June 2013 in a Randomized Complete Block Design (RCBD) with three replications. The experiment was carried out at two irrigation levels (normal and drought stress at flowering stage). Each plot consisted of one row of $150 \mathrm{~cm}$ long and 25 and $10 \mathrm{~cm}$ space between rows and within rows, respectively. Lentil lines were sown on 07 March, 2013. Weeding and other management practices were done when necessary. Drought stress was imposed by cutting irrigation at $50 \%$ flowering stage of the crop. When the plants of each line showed drought stressed symptom, five plants from each line were selected randomly. The plants were harvested on $30 \mathrm{July}, 2013$, then some traits such as biological yield (g), pod number per plant, pod weight per plant $(\mathrm{g}), 100$-grain weight $(\mathrm{g})$, plant height $(\mathrm{cm})$, leaf length, leaf width $(\mathrm{cm})$, seed diameter $(\mathrm{mm}), \mathrm{HI}(\%)$ and seed yield per plant $(\mathrm{g})$ were measured.

\section{Statistical analysis}

Analysis of variances was performed using SAS 9.2 software (SAS Institute, 2008). LSD test was used for mean comparison. Reduction percentage in the mean value of each trait due to drought stress was calculated as follow:

$$
\mathrm{C}=\frac{\overline{\mathrm{X}}_{\mathrm{ns}}-\overline{\mathrm{X}}_{\mathrm{ds}}}{\overline{\mathrm{X}}_{\mathrm{ns}}}
$$

Where $\overline{\mathrm{X}}_{\mathrm{ns}}$ and $\overline{\mathrm{X}}_{\mathrm{ds}}$ are the means of traits in normal and stress conditions, respectively. For understanding relationships between traits with seed yield, Pearson correlation coefficient and Stepwise regression analysis were used. Broadsence heritability was estimated with genetic variance to phenotypic variance ratio $\left(\frac{\delta_{g}^{2}}{\delta_{p}^{2}}\right)$ (Falconer, 1996). For evaluating tolerance in the studied lines, STI (Stress Tolerance Index) were computed as follow (Fernandez, 1992):

$$
\mathrm{STI}=\frac{Y_{p i} * Y_{s i}}{? \mathrm{p}^{2}}
$$

where $\mathrm{Y}_{P i}$ and $\mathrm{Y}_{S i}$ are the seed yield of lines in normal and stress conditions, respectively, and $?_{\mathrm{n}}$ is the mean of all lines in normal conditions. 


\section{Results and Discussion}

Results of analysis of variance showed that significant differences exist in terms of all studied traits between normal and stress condition and also among studied lines (Table 1) as well as, interaction effect of line $\times$ environment for all traits. It indicates that not only the levels of irrigation had different effects on characters, but studied lines had also different reactions to terminal drought stress. These results reveal the high values of genetic diversity. Bayoumi (2008) in a study of effect of different irrigations on 27 genotypes of lentil stated that high genetic diversity existed in terms of studied traits and effect of line $\times$ environment. Kumar et al. (2012) observed high diversity for biological yield, seed yield and $\mathrm{HI}$ in 43 genotypes of lentil in drought stress condition. Based on coefficient of variations $(\mathrm{CV})$, it could be stated that experiment had carried out with acceptable accuracy. Leaf width and biological yield had the highest and the lowest CV values, respectively. Table 2 shows the percentage reduction of traits mean in normal and drought condition. The results revealed that drought stress decreased all the traits except for leaf width (Table 2). With the view to \%reduction, it was clear that reaction of characters due to drought stress was different. It was observed from Table 2 that water deficient had the highest effect on pod weight per plant, seed yield and pod number per plant, so as to reduce them $54 \%, 45.3 \%$ and $42.2 \%$, respectively. Traits associated to leaf (length and width of leaf) had the minimum unaffected from stress. Hosseini et al. (2011) pointed out that irrigating in flowering stage increased 52\% seed yield of lentil compared to condition without irrigation. Drought stress or water deficient had significant impact on yield and its components and in a study of Panahyan-e-Kivi et al. (2009) drought stress reduced the pod number per plant, seed number per pod and 100 grain weight.

Study of correlation is a useful tool for determination of extent and direction of the relationship between different variables with seed yield (Gashaw et al., 2007). According to the results, a positive and significant correlation between biological yield, pod weight per plant, pod number per plant and HI were observed in both the conditions (Table 3). Plant height had a positive and significant correlation with seed yield only in normal condition. This result is compatible with Sarker et al. (2003). It revealed from Table 3 that a significant positive correlation exists between leaf width and grain yield in normal condition; while correlation of leaf length with grain yield under drought stress condition was negative and significant. Kumar et al. (2012) observed significant and positive correlations between seed yield with seedling vigour, number of pods per plant, biological yield, HI and chlorophyll content under drought stress condition. In the present study, the seed diameter had negative correlation with grain yield in drought condition (Table 3 ). 
EFFECT OF DROUGHT STRESS ON AGRO-MORPHOLOGICAL TRAITS OF LENTIL 211

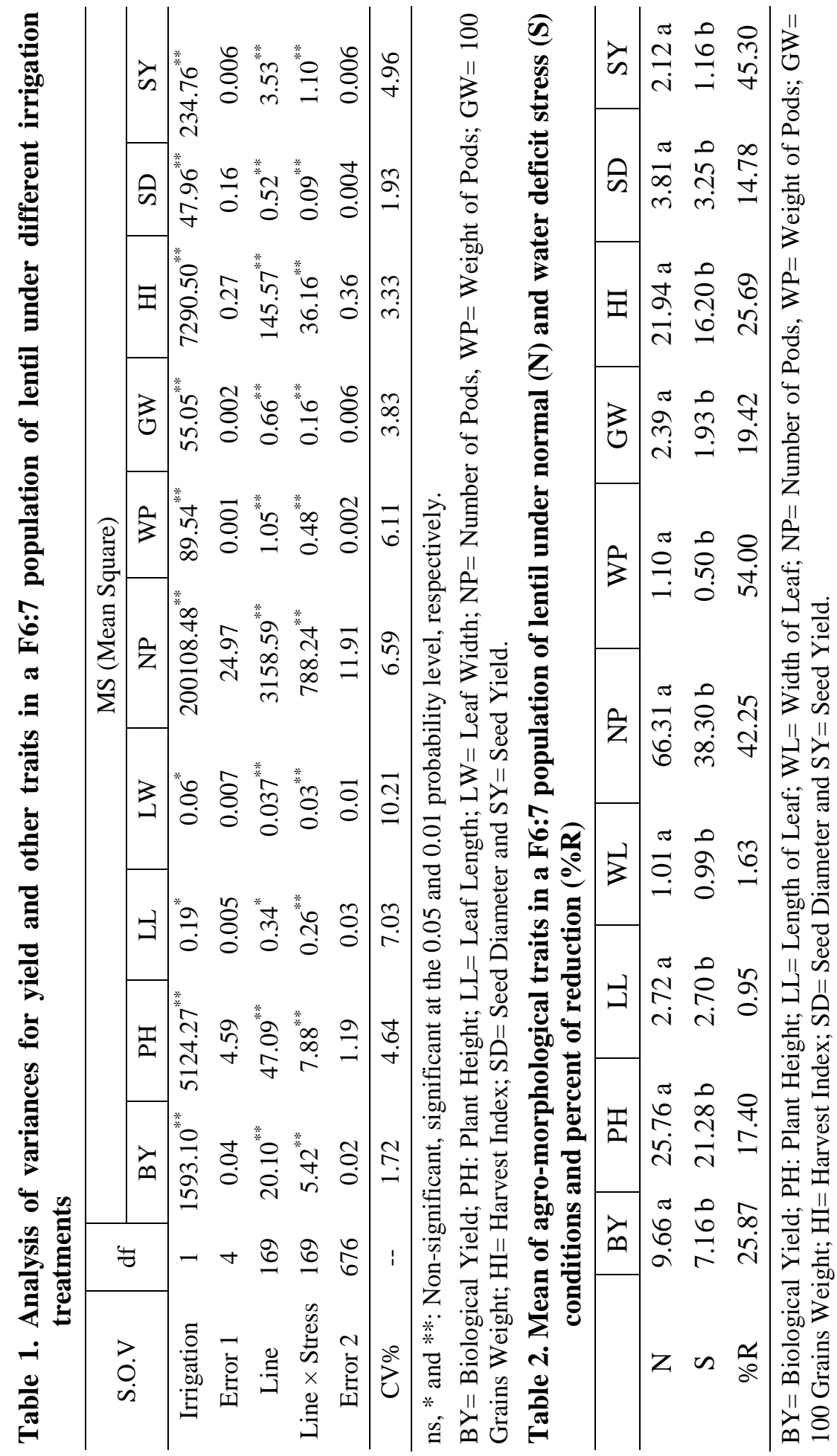




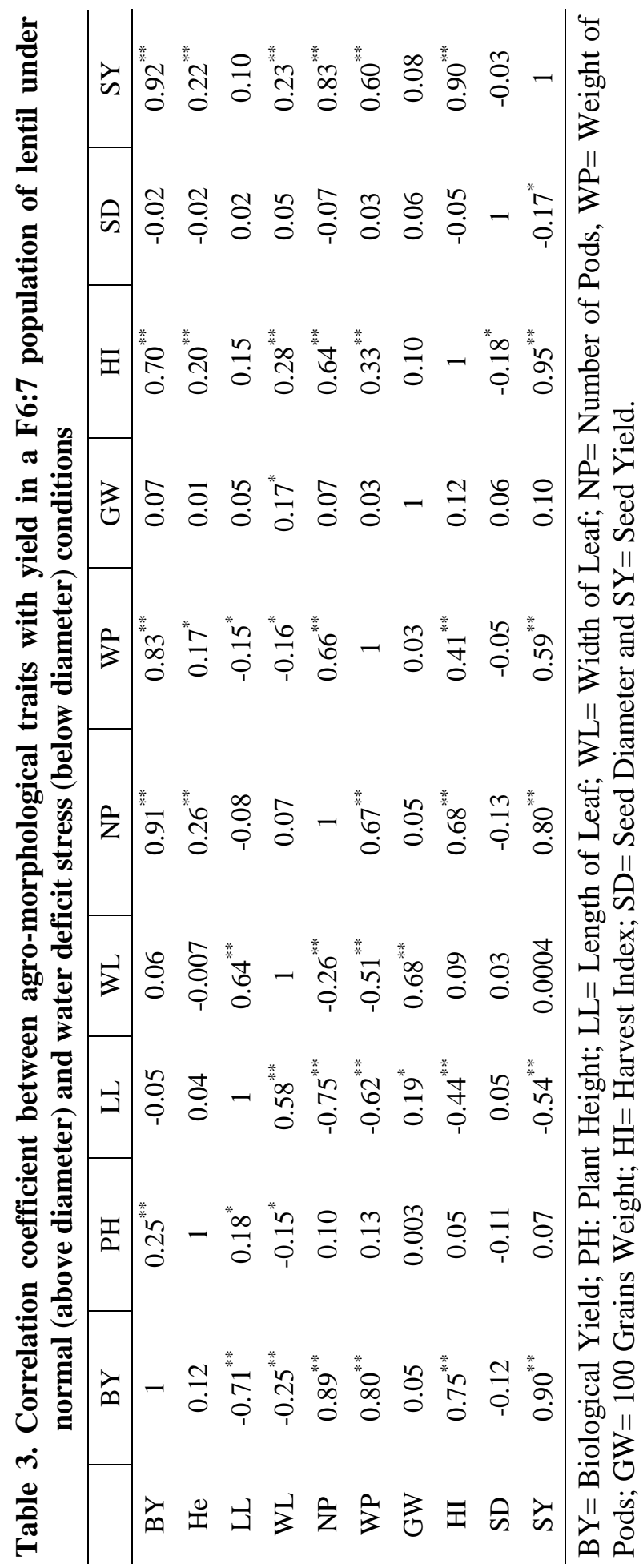


According to the results of the regression analysis (Table 4), 10 independent variables were introduced to model in four steps, and finally $87.6 \%$ of yield changes were determined by the biological yield, HI, pod weight per plant and leaf length as input variables .

Table 4. Indicators of Stepwise regression of traits in yield (g/per plant)

\begin{tabular}{c|c|c|c|c}
\hline Step & $\begin{array}{c}\mathrm{R} \text { (Multiple } \\
\text { correlation } \\
\text { coefficient) }\end{array}$ & $\begin{array}{c}\left(\mathrm{R}^{2}\right) \text { Determination } \\
\text { coefficient }\end{array}$ & $\begin{array}{c}\left(\mathrm{R}^{2} \text { Ad) Modified }\right. \\
\text { determination } \\
\text { coefficient }\end{array}$ & (Std. Error) \\
\hline 1 & 0.878 & 0.772 & 0.772 & 0.35 \\
2 & 0.930 & 0.866 & 0.866 & 0.18 \\
3 & 0.933 & 0.871 & 0.871 & 0.17 \\
4 & 0.983 & 0.876 & 0.876 & 0.15 \\
\hline
\end{tabular}

The results of ANOVA for validating of final model showed that the model was significant (Table 5).

Table 5. Results of stepwise regression analysis for seed yield (per plant)

\begin{tabular}{|c|c|c|c|c|c|c|}
\hline \multicolumn{7}{|c|}{ ANOVA } \\
\hline Model & S.O.V & $\begin{array}{l}\text { Sum of } \\
\text { Squares }\end{array}$ & $\mathrm{df}$ & Mean Square & F & $\begin{array}{c}\text { Significant } \\
\text { level }\end{array}$ \\
\hline \multirow{3}{*}{4} & Regression & 998.457 & 4 & 249.614 & 10261.747 & 0.000 \\
\hline & Residual & 24.690 & 1015 & 0.024 & & \\
\hline & Total & 1023.147 & 1019 & & & \\
\hline
\end{tabular}

According to Table 5, equation derived from stepwise regression for seed yield was as follow:

Seed Yield $=-2.738+0.423(B Y)+0$

Seed Yield $=-2.738+0.423(\mathrm{BY})+0.057(\mathrm{HI})-0.412(\mathrm{WP})+0.191(\mathrm{LL}), \mathrm{R}^{2}=$ 0.876

Where BY is biological yield, $\mathrm{HI}$ is harvest index, WP is pod weight pre plant and LL is leaf length.

In accordance to Standardized regression coefficients (Table 6), biological yield determine more yield changes in comparison with other variables. After it, HI and pod weight per plant were considered as positive and negative factors, respectively, to achieve high yield. It seemed that biological yield and pod weight could be used as main keys for indirect selection. Aghili et al. (2012) used stepwise regression and reported that increasing in biological yield would have desirable effect on seed yield. Tadayyon et al. (2011) stated that using standard multiple regression analysis it could be useful to investigate the relationship 
between yield and 100-seed weight, number of seeds per pod and number of pods per plant highly affected seed yield.

Table 6. Coefficient and indicators of stepwise regression related to measured traits on seed yield (per plant)

\begin{tabular}{l|c|c|c|c|c}
\hline Model & $\begin{array}{c}\text { Regression } \\
\text { coefficient }\end{array}$ & Std. Error & $\begin{array}{c}\text { Standardized } \\
\text { regression } \\
\text { coefficients }\end{array}$ & t-Test & $\begin{array}{c}\text { Significant } \\
\text { level }\end{array}$ \\
\hline Intercept & -2.738 & 0.057 & & -48.392 & 0.000 \\
Biological Yield & 0.423 & 0.012 & 1.018 & 36.751 & 0.000 \\
Harvest Index (\%) & 0.057 & 0.002 & 0.349 & 36.337 & 0.000 \\
Weight of Pods Per Plant & -0.412 & 0.024 & -0.241 & -17.207 & 0.000 \\
Length of leaf & 0.191 & 0.014 & 0.067 & 13.838 & 0.000 \\
\hline
\end{tabular}

The estimation of genetic variance $(\mathrm{Vg})$, phonotypic variance $(\mathrm{Vp})$, genotypic coefficient of variation $(\mathrm{CVg})$ and phonotypic coefficient of variation $(\mathrm{CVp})$ from ANOVA were showed in Table 7. It was observed that the values of $\mathrm{Vp}$ and $\mathrm{CVp}$ were more than in contrast to values that related to $\mathrm{Vg}$ and $\mathrm{CVg}$ in all traits. This is proved more contributions of environment in expression of these characters (Makeen et al., 2007).

Maximum values of $\mathrm{CVg}$ were observed for seed yield (38.84\%), pod weight per plant $(38.47 \%)$ and pod number per plant $(38 \%)$. In contrast, the highest values of CVp were in pod weight per plant (63.19\%), seed yield $(53.75 \%)$ and pod number per plant (49.33). High values of CVg and CVp for seed yield and pod number per plant were reported by Sadiq et al. (2000) and Sarwar et al. (2013).

Table 7. Estimates of variance components, coefficient of variation and heritability in a F6:7 population of lentil under normal and water deficit stress conditions

\begin{tabular}{l|c|c|c|c|c}
\hline Traits & $\mathrm{Vg}$ & $\mathrm{Vp}$ & $\mathrm{CVg} \%$ & $\mathrm{CVp} \%$ & $\mathrm{~h}^{2}$ \\
\hline Biological Yield & 2.45 & 4.27 & 18.59 & 24.56 & 0.57 \\
Height & 6.54 & 9.96 & 10.87 & 13.41 & 0.66 \\
Length of Leaf & 0.01 & 0.12 & 4.26 & 12.78 & 0.11 \\
Width of Leaf & 0.06 & 0.07 & 23.75 & 27.02 & 0.77 \\
Number of Pods & 395.06 & 665.75 & 38.00 & 49.33 & 0.59 \\
Weight of Pods & 0.10 & 0.26 & 38.47 & 63.19 & 0.37 \\
100 Grains Weight & 0.08 & 0.14 & 13.36 & 17.36 & 0.59 \\
Harvest Index & 18.24 & 30.53 & 23.54 & 30.46 & 0.60 \\
Seed Diameter & 0.07 & 0.10 & 7.59 & 9.16 & 0.69 \\
Seed Yield & 0.41 & 0.78 & 38.84 & 53.75 & 0.52 \\
\hline
\end{tabular}

$\mathrm{Vg}=$ Genetic variance, $\mathrm{Vp}=$ Phenotypic variance, $\mathrm{CVg} \%=$ Genotypic coefficient of variation, $\mathrm{CVp} \%=$ Phenotypic coefficient of variation, $\mathrm{h}^{2}=$ Heritability. 
Maximum heritability was in leaf width $\left(h^{2}=0.77\right)$, seed diameter $\left(h^{2}=0.69\right)$ and height $\left(h^{2}=0.66\right)$ that indicated the low environmental effect on them in contrast to other traits. Such traits could be used as powerful tools for selecting of lentil genotypes. Heritability for seed yield was 0.52 . For other traits moderate heritability were estimated except leaf width. According to Younis et al. (2008) high heritability exists in seed yield, HI and days to flowering. Tyagi and Khan (2010) stated that pod number per plant, 100-seed weight, HI and seed yield had high heritability.

Stress Tolerance Index (STI) introduced by Fernandez (1992) is a perfect tool to select, determine and identify the genotypes that have the maximum yield in normal and stress conditions. STI index revealed that the studied lines had high diversity in reflected to terminal drought stress (Table 8). While Lines 160 and 125 in normal condition and lines 125 and 63 in stress condition had maximum values of seed yield, lines 93 and 98 had the lowest productivity in both conditions. Seed yield of L3685 was more than Ghazvin in both conditions. L3685 parent was also more tolerant to other parent (Ghazvin). In accordance with Table 5, it revealed that lines 125 and 160 were the most tolerant lines comparing to other lines. Therefore to cultivate in the area where lentil lines faces terminal drought stress, these lines might be recommended. On other hand, lines 93 and 98 were the most sensitive to drought stress.

\section{Conclusion}

Drought stress caused the significant reduction in yield and its components. Results indicated that considerable variations exist related to biological yield, pod number per plant, pod weight per plant, 100-grain weight, plant height, leaf length, leaf width, seed diameter and harvest index among the lentil lines. These characters could be used for screening to drought stress tolerance of lentil. The results showed that biological yield, number and weight of pods were the main keys for indirect selection for resistance to water deficient. Two lines (125 and 160) have been found that had remarkable resistance to drought stress.

Table 8. Stress Tolerance Index (STI) in a F6:7 population of lentil under normal (Yp) and water deficit stress (Ys).

\begin{tabular}{c|c|c|c|c|c|c|c}
\hline Line & $\begin{array}{c}\text { Yp (g per } \\
\text { Plant) }\end{array}$ & $\begin{array}{c}\text { Ys (g per } \\
\text { plant) }\end{array}$ & STI & Line & $\begin{array}{c}\text { Yp (g per } \\
\text { Plant })\end{array}$ & $\begin{array}{c}\text { Ys (g per } \\
\text { plant })\end{array}$ & STI \\
\hline $\mathbf{1}$ & 2.73 & 1.75 & 1.06 & $\mathbf{5 1}$ & 2.18 & 1.46 & 0.71 \\
$\mathbf{2}$ & 2.62 & 1.96 & 1.15 & $\mathbf{5 2}$ & 0.64 & 0.55 & 0.08 \\
$\mathbf{3}$ & 2.25 & 2.01 & 1.01 & $\mathbf{5 3}$ & 1.30 & 0.43 & 0.13 \\
$\mathbf{4}$ & 0.66 & 0.37 & 0.05 & $\mathbf{5 4}$ & 3.66 & 1.63 & 1.33 \\
$\mathbf{5}$ & 2.18 & 1.39 & 0.68 & $\mathbf{5 5}$ & 2.28 & 0.32 & 0.16 \\
$\mathbf{6}$ & 1.54 & 1.36 & 0.47 & $\mathbf{5 6}$ & 2.37 & 1.65 & 0.87 \\
\hline
\end{tabular}


RAHIMI et al.

Table 8. Cont'd

\begin{tabular}{|c|c|c|c|c|c|c|c|}
\hline Line & $\begin{array}{l}\text { Yp (g per } \\
\text { Plant) }\end{array}$ & $\begin{array}{l}\text { Ys (g per } \\
\text { plant) }\end{array}$ & STI & Line & $\begin{array}{l}\text { Yp (g per } \\
\text { Plant) }\end{array}$ & $\begin{array}{l}\text { Ys (g per } \\
\text { plant) }\end{array}$ & STI \\
\hline 7 & 1.93 & 0.84 & 0.36 & 57 & 1.83 & 0.53 & 0.22 \\
\hline 8 & 1.23 & 1.14 & 0.31 & 58 & 2.32 & 1.05 & 0.54 \\
\hline 9 & 1.85 & 1.35 & 0.56 & 59 & 4.67 & 1.26 & 1.31 \\
\hline 10 & 2.43 & 1.96 & 1.06 & 60 & 2.44 & 0.61 & 0.33 \\
\hline 11 & 2.92 & 2.55 & 1.66 & 61 & 2.51 & 1.19 & 0.67 \\
\hline 12 & 1.55 & 1.22 & 0.42 & 62 & 1.49 & 0.51 & 0.17 \\
\hline 13 & 1.71 & 1.52 & 0.58 & 63 & 2.25 & 0.75 & 0.37 \\
\hline 14 & 1.27 & 0.75 & 0.21 & 64 & 1.84 & 0.50 & 0.21 \\
\hline 15 & 2.49 & 1.52 & 0.84 & 65 & 1.59 & 0.83 & 0.29 \\
\hline 16 & 0.77 & 0.43 & 0.07 & 66 & 1.87 & 1.38 & 0.57 \\
\hline 17 & 2.10 & 1.38 & 0.64 & 67 & 1.15 & 0.56 & 0.14 \\
\hline 18 & 2.03 & 1.76 & 0.80 & 68 & 1.50 & 0.54 & 0.18 \\
\hline 19 & 1.13 & 0.72 & 0.18 & 69 & 3.13 & 2.23 & 1.55 \\
\hline 20 & 0.86 & 0.43 & 0.08 & 70 & 1.18 & 0.84 & 0.22 \\
\hline 21 & 0.71 & 0.34 & 0.05 & 71 & 2.85 & 1.87 & 1.19 \\
\hline 22 & 1.37 & 0.96 & 0.29 & 72 & 2.51 & 1.48 & 0.83 \\
\hline 23 & 1.34 & 0.94 & 0.28 & 73 & 2.07 & 1.71 & 0.79 \\
\hline 24 & 1.17 & 0.69 & 0.18 & 74 & 3.15 & 1.19 & 0.84 \\
\hline 25 & 1.06 & 0.66 & 0.15 & 75 & 3.56 & 0.62 & 0.49 \\
\hline 26 & 1.94 & 1.01 & 0.44 & 76 & 1.41 & 1.10 & 0.35 \\
\hline 27 & 2.04 & 1.12 & 0.51 & 77 & 2.07 & 1.43 & 0.66 \\
\hline 28 & 0.91 & 0.51 & 0.10 & 78 & 1.80 & 1.29 & 0.52 \\
\hline 29 & 1.47 & 0.76 & 0.25 & 79 & 4.77 & 1.81 & 1.93 \\
\hline 30 & 1.24 & 0.74 & 0.21 & 80 & 3.76 & 1.36 & 1.14 \\
\hline 31 & 0.76 & 0.54 & 0.09 & 81 & 3.69 & 2.35 & 1.94 \\
\hline 32 & 1.24 & 0.93 & 0.26 & 82 & 4.36 & 1.40 & 1.36 \\
\hline 33 & 1.25 & 0.49 & 0.14 & 83 & 1.66 & 0.42 & 0.15 \\
\hline 34 & 1.97 & 1.33 & 0.58 & 84 & 2.45 & 1.28 & 0.70 \\
\hline 35 & 2.71 & 0.67 & 0.41 & 85 & 1.37 & 0.67 & 0.20 \\
\hline 36 & 2.38 & 1.98 & 1.05 & 86 & 1.59 & 1.91 & 0.68 \\
\hline 37 & 2.22 & 1.25 & 0.62 & 87 & 2.73 & 1.33 & 0.81 \\
\hline 38 & 1.65 & 1.04 & 0.38 & 88 & 1.74 & 1.20 & 0.46 \\
\hline 39 & 1.85 & 1.16 & 0.48 & 89 & 1.57 & 1.12 & 0.39 \\
\hline 40 & 1.44 & 0.73 & 0.23 & 90 & 0.62 & 0.33 & 0.05 \\
\hline 41 & 1.49 & 0.85 & 0.28 & 91 & 1.04 & 0.54 & 0.12 \\
\hline 42 & 2.89 & 1.64 & 1.06 & 92 & 0.77 & 0.43 & 0.07 \\
\hline
\end{tabular}


EFFECT OF DROUGHT STRESS ON AGRO-MORPHOLOGICAL TRAITS OF LENTIL 217 Table 8. Cont'd

\begin{tabular}{c|c|c|c|c|c|c|c}
\hline Line & $\begin{array}{c}\text { Yp }(\mathrm{g} \text { per } \\
\text { Plant) }\end{array}$ & $\begin{array}{c}\text { Ys }(\mathrm{g} \text { per } \\
\text { plant })\end{array}$ & STI & Line & $\begin{array}{c}\text { Yp }(\mathrm{g} \text { per } \\
\text { Plant }\end{array}$ & $\begin{array}{c}\text { Ys }(\mathrm{g} \text { per } \\
\text { plant }\end{array}$ & STI \\
\hline $\mathbf{4 3}$ & 2.52 & 0.88 & 0.50 & $\mathbf{9 3}$ & 0.52 & 0.32 & 0.04 \\
$\mathbf{4 4}$ & 2.21 & 1.05 & 0.52 & $\mathbf{9 4}$ & 0.76 & 0.73 & 0.12 \\
$\mathbf{4 5}$ & 1.60 & 1.45 & 0.52 & $\mathbf{9 5}$ & 1.14 & 0.58 & 0.15 \\
$\mathbf{4 6}$ & 2.16 & 1.45 & 0.70 & $\mathbf{9 6}$ & 2.15 & 1.80 & 0.86 \\
$\mathbf{4 7}$ & 1.09 & 0.74 & 0.18 & $\mathbf{9 7}$ & 1.45 & 1.38 & 0.45 \\
$\mathbf{4 8}$ & 4.66 & 2.84 & 2.95 & $\mathbf{9 8}$ & 0.52 & 0.22 & 0.03 \\
$\mathbf{4 9}$ & 2.76 & 1.20 & 0.74 & $\mathbf{9 9}$ & 0.87 & 0.65 & 0.13 \\
$\mathbf{5 0}$ & 1.77 & 1.31 & 0.52 & $\mathbf{1 0 0}$ & 0.75 & 0.57 & 0.10 \\
$\mathbf{1 0 1}$ & 1.10 & 0.55 & 0.13 & $\mathbf{1 3 6}$ & 3.51 & 1.03 & 0.81 \\
$\mathbf{1 0 2}$ & 1.45 & 1.26 & 0.41 & $\mathbf{1 3 7}$ & 2.35 & 1.06 & 0.55 \\
$\mathbf{1 0 3}$ & 4.18 & 2.76 & 2.57 & $\mathbf{1 3 8}$ & 4.52 & 1.33 & 1.34 \\
$\mathbf{1 0 4}$ & 4.51 & 0.96 & 0.97 & $\mathbf{1 3 9}$ & 2.20 & 1.32 & 0.65 \\
$\mathbf{1 0 5}$ & 0.65 & 0.57 & 0.08 & $\mathbf{1 4 0}$ & 1.94 & 0.92 & 0.40 \\
$\mathbf{1 0 6}$ & 1.93 & 1.58 & 0.68 & $\mathbf{1 4 1}$ & 2.05 & 0.94 & 0.43 \\
$\mathbf{1 0 7}$ & 3.75 & 1.10 & 0.92 & $\mathbf{1 4 2}$ & 3.33 & 1.02 & 0.75 \\
$\mathbf{1 0 8}$ & 2.73 & 1.89 & 1.15 & $\mathbf{1 4 3}$ & 2.03 & 1.67 & 0.75 \\
$\mathbf{1 0 9}$ & 1.85 & 1.65 & 0.68 & $\mathbf{1 4 4}$ & 2.00 & 0.52 & 0.23 \\
$\mathbf{1 1 0}$ & 1.12 & 0.79 & 0.20 & $\mathbf{1 4 5}$ & 4.32 & 1.86 & 1.79 \\
$\mathbf{1 1 1}$ & 0.84 & 0.75 & 0.14 & $\mathbf{1 4 6}$ & 3.10 & 0.65 & 0.45 \\
$\mathbf{1 1 2}$ & 1.12 & 0.56 & 0.14 & $\mathbf{1 4 7}$ & 2.95 & 0.72 & 0.47 \\
$\mathbf{1 1 3}$ & 2.46 & 1.84 & 1.01 & $\mathbf{1 4 8}$ & 3.76 & 1.41 & 1.18 \\
$\mathbf{1 1 4}$ & 2.72 & 1.20 & 0.73 & $\mathbf{1 4 9}$ & 3.03 & 2.67 & 1.80 \\
$\mathbf{1 1 5}$ & 1.23 & 0.83 & 0.23 & $\mathbf{1 5 0}$ & 2.45 & 1.51 & 0.83 \\
$\mathbf{1 1 6}$ & 2.27 & 1.11 & 0.56 & $\mathbf{1 5 1}$ & 3.44 & 0.54 & 0.42 \\
$\mathbf{1 1 7}$ & 1.64 & 0.98 & 0.36 & $\mathbf{1 5 2}$ & 2.25 & 1.12 & 0.56 \\
$\mathbf{1 1 8}$ & 1.36 & 0.99 & 0.30 & $\mathbf{1 5 3}$ & 1.93 & 1.14 & 0.49 \\
$\mathbf{1 1 9}$ & 1.73 & 1.95 & 0.75 & $\mathbf{1 5 4}$ & 1.32 & 1.37 & 0.40 \\
$\mathbf{1 2 0}$ & 1.74 & 0.77 & 0.30 & $\mathbf{1 5 5}$ & 1.01 & 1.03 & 0.23 \\
$\mathbf{1 2 1}$ & 2.09 & 1.81 & 0.84 & $\mathbf{1 5 6}$ & 3.14 & 1.70 & 1.19 \\
$\mathbf{1 2 2}$ & 2.13 & 1.08 & 0.51 & $\mathbf{1 5 7}$ & 2.27 & 0.88 & 0.44 \\
$\mathbf{1 2 3}$ & 1.52 & 0.95 & 0.32 & $\mathbf{1 5 8}$ & 1.98 & 1.12 & 0.49 \\
$\mathbf{1 2 4}$ & 1.54 & 1.62 & 0.56 & $\mathbf{1 5 9}$ & 2.95 & 1.52 & 1.00 \\
$\mathbf{1 2 5}$ & 5.86 & 2.93 & 3.83 & $\mathbf{1 6 0}$ & 7.11 & 1.93 & 3.06 \\
$\mathbf{1 2 6}$ & 1.42 & 0.78 & 0.25 & $\mathbf{1 6 1}$ & 2.87 & 1.34 & 0.86 \\
\hline & & & & & & & \\
\hline
\end{tabular}


Table 8. Cont'd

\begin{tabular}{c|c|c|c|c|c|c|c}
\hline Line & $\begin{array}{c}\text { Yp (g per } \\
\text { Plant) }\end{array}$ & $\begin{array}{c}\text { Ys (g per } \\
\text { plant) }\end{array}$ & STI & Line & $\begin{array}{c}\text { Yp (g per } \\
\text { Plant) }\end{array}$ & $\begin{array}{c}\text { Ys (g per } \\
\text { plant) }\end{array}$ & STI \\
\hline $\mathbf{1 2 7}$ & 1.55 & 0.98 & 0.34 & $\mathbf{1 6 2}$ & 2.61 & 1.77 & 1.03 \\
$\mathbf{1 2 8}$ & 1.45 & 0.84 & 0.27 & $\mathbf{1 6 3}$ & 2.09 & 1.38 & 0.65 \\
$\mathbf{1 2 9}$ & 4.93 & 2.30 & 2.53 & $\mathbf{1 6 4}$ & 1.46 & 1.16 & 0.38 \\
$\mathbf{1 3 0}$ & 3.34 & 2.10 & 1.56 & $\mathbf{1 6 5}$ & 2.09 & 1.23 & 0.58 \\
$\mathbf{1 3 1}$ & 2.43 & 1.62 & 0.88 & $\mathbf{1 6 6}$ & 2.05 & 0.94 & 0.43 \\
$\mathbf{1 3 2}$ & 0.87 & 0.64 & 0.12 & $\mathbf{1 6 7}$ & 1.16 & 0.43 & 0.11 \\
$\mathbf{1 3 3}$ & 0.76 & 0.47 & 0.08 & $\mathbf{1 6 8}$ & 1.15 & 0.84 & 0.21 \\
$\mathbf{1 3 4}$ & 1.35 & 0.77 & 0.23 & Ghazvin & 1.85 & 0.86 & 0.36 \\
$\mathbf{1 3 5}$ & 2.67 & 0.95 & 0.56 & L-3685 & 2.53 & 1.53 & 0.86 \\
\hline
\end{tabular}

\section{References}

Aghili, P., A. Imani, H. Shahbazi and Y. Alaei. 2012. Study of correlation and relationships between seed yield and yield components in Lentil (Lens culinaris Medik). Ann. Biol. Res. 3: 5042-5045.

Bayoumi, T.Y. 2008. Genetic diversity among lentil genotypes for drought tolerance. J. Agric. Invest. 25-35.

Blum, A. 2002. Drought stress and its impact [Internet]. Plant stress.com. Available from: http://www. plantstress. com/Articles/drought_i/drought_i. htm.

Erskine, W. and A. Sarker. 2004. Lentil. In: Corke H, Walker CE (Eds). Encyclopedia of grain sciences. London: Elsevier; P. 142-150.

Falconer, D.S., T.F. Mackay and R. Frankham. 1996. Introduction to quantitative genetics. $4^{\text {th }}$ ed. Trends in Genetics: 12(7), 280.

FAO. 2013. Food and Agriculture Organization. http://faostat.fao.org/.Accessed November, 2013.

Fernandez, G.C.I. 1992. Effective selection criteria for assessing plant stress tolerance. In: Kuo CG (ed.) Adaptation of Food Crops to Temperature and Water Stress. Proceedings of International Conferences for water stress. Taiwan: Asian Vegetable Research Development Center. Pp. 257-270.

Fouad, M., M. Imtiaz, S. Kumar and R. Malhotra. 2011. Breeding food legumes for enhanced drought and heat tolerance to cope with climate change. In: Solh, M. and M.C. Saxena (ed.), Food Security and Climate Change in Dry Areas. Proceedings of International Conference. Syria: ICARDA; Pp. 244-254.

Gashaw, A., H. Mohammed and H. Singh. 2007. Selection criterion for improved grain yields in Ethiopian durum wheat genotypes. Afri. Crop Sci. J. 15(1):25-31.

Hosseini, F.S., A. Nezami, M. Parsa, and K. Hajmohammadnia. 2011. Effects of supplementary irrigation on yield and yield components of lentil (Lens culinaris Medik.) cultivars in Mashhad climate. J. Water and Soil. 25(3): 625-633. 
Kumar, J., P.S. Basu, E. Srivastava, S.K. Chaturvedi, N. Nadarajan and S. Kumar. 2012. Phenotyping of traits imparting drought tolerance in lentil. Crop Pasture Sci. 63: 547-554.

Makeen, K., A. Garad, J. Arif and A.K. Singh. 2007. Genetic variability and correlation studies on yield and its components in mungbean [Vigna radiata L. Wilczek]. $J$. Agron. 6: 216-218.

Muehlbauer, F.J. 2009. Lentil: improvement in developing countries. In: Erskine, W., F.J. Muehlbauer, A. Sarker and B. Sharma (Ed.), The Lentil: Botany, Production and Uses, UK: International Oxford; Pp. 137-154.

Oweis, T., A. Hachum and M. Pala. 2004. Lentil production under supplemental irrigation in a Mediterranean environment. Agric. Water Manag. 68(3): 251-265.

Panahyan-e-Kivi, M., A. Ebadi, T. Ahmad and Sh. Jamaati-e-Somarin. 2009. Evaluation of yield and yield components of lentil genotypes under drought stress. Res. J. Environ. Sci. 3: 456-460.

Sadiq, M.S., G. Sarwar and G. Abbas. 2000. Selection criteria for seed yield in mungbean (Vigna radiate L. Wilczek). J. Agric. Res. 38: 7-12.

Saha, C., A. Sarker, W. Chen, J. Vandemark and J. Muehlbauer. 2013. Inheritance and linkage map positions of genes conferring agromorphological traits in Lens culinaris Medik. Int. J. Agron. 2013: 618926.

Sarker, A., W. Erskine and M. Singh. 2003. Regression models for lentil seed and straw yields in Near East. Agric. forest meteorol. 116: 61-72.

Sarwar, G., G. Abbas and M. Jawad Asghar. 2013. Quantitative analysis of yield related traits in lentil (Lens Culinaris Medik.) germplasm. J. Agric. Res. 51: 239-246.

SAS Institute. 2008. SAS software. Version 9.2.

Silim, S.N., M.C. Saxena and W. Erskine. 1993. Adaptation of lentil to the Mediterranean environment. I. Factors affecting yield under drought conditions. Exp. Agric. 27: $155-175$.

Tadayyon, A., L. Hashemi and M. Khodambashi. 2011. Effective morphological and phenological traits on seed and biological yield in lentil genotypes in Shahrekord region. Iran. J. Pulses Res. 2: 47-62.

Tyagi, S.D. and M.H. Khan. 2010. Studies on genetic variability and interrelationship among different traits in microsperma lentil (Lens culinaris Medik). J. Agric. Biotech. Sustain. Dev. 2: 15-20.

Wang, W., B. Vinocur and A. Altman. 2003. Plant responses to drought, salinity and extreme temperatures: towards genetic engineering for stress tolerance. Planta. 218: $1-14$.

Younis, N., M. Hanif, M.S. Sadiq, G. Abbas, M.J. Asghar and M.A. Haq. 2008. Estimates of genetic parameters and path analysis in lentil. Pak. J. Agri. Sci: 45: 44-48. 